\title{
The Competition between London Companies Regarding Their Financial Performance
}

\section{- Simionescu Mibaela}

\begin{abstract}
There is a high level of competition between companies and the final result is often measured by their financial performance. The main purpose of this study is to evaluate the financial performance of a sample of companies from London. Statistical analysis is performed of 293 companies randomly selected from the population of firms resident in London, the economic indicators being registered for 2014. The main results indicated that most of the variation in financial performance is explained by the book-to-market ratio and cash-to-assets ratio. On the other hand, financial performance is also explained by cash flow and leverage. Most of the firms that were placed in the same group had a successful financial performance in 2014. Few companies located in the other cluster encountered some difficulties regarding cash flow and sales. This situation could be explained by the difficulties of facing the economic crisis. Thus the financial performance evaluation is useful in improving a firm's financial indicators in order to achieve a higher profit. The diagnosis will help managers in taking the most suitable decisions to solve the financial problems by selecting the best strategies.
\end{abstract}

Keywords: financial performance, competition, cash flow, book-to-market, leverage, cash-to-assets JEL Classification: C10, C38, M21

\section{INTRODUCTION}

Competition between firms often takes place in order to obtain the greatest profit, ensured by the highest sales. In this context, the financial performance of the company remains the criterion that shows if a firm has succeeded in achieving its objectives on the market. Consequently, it is important to measure the financial performance and classify the companies according to this criterion.

There are several approaches to assessing a company's performance. The studies attempted to find out the relationship between different performance dimensions. In this study, the financial performance of London companies was assessed. The statistical analysis was based on correlations that were put into evidence by using data analysis methods (principal components analysis and cluster analysis).

Decision making at managerial level is based on a rigorous assessment of firm performance and it is followed by the control stage. The analysis of financial performance should be the basis for a predictive approach regarding the evolution of the company (Flammer, 2015). Moreover, the performance assessment helps managers improve the future financial performance by taking into consideration specific measures to overcome the problems that have been identified.

Several studies were proposed for UK firms, the government showing the necessity to select the 
best performance management system to assess the company and to provide the best solution for business success.

The study is structured into several sections. After this introduction, a short literature review is conducted. The proper performance assessment is made for a sample of 293 London firms in 2014. The last section draws conclusions.

\section{FINANCIAL PERFORMANCE ASSESSMENT}

In order to survive and succeed, companies have to follow strategic directions, fix goals, implement decisions, and evaluate their state as they proceed towards the goals that have been established (Ameer \& Othman, 2012). If the company becomes large enough, the manager cannot assess the state the firm is in and the company has to implement a performance management system and a control procedure. In the past few decades, technological information has been used to ensure the control and sense capability. The tools offered by vendors refer to statistical analysis, machine learning, artificial intelligence, reporting and web charting, expert system technology, application and data integration approach. These tools are used in practice to analyze firms' performance.

The determinants of business performance are a topic in progress to which studies have been dedicated in the last few years. Performance indicators have been employed for testing the business theory (Eccles \& Pyburn, 1992) or for facilitating strategic learning (Kaplan \& Norton, 1996). Causal relationships between performance dimensions were identified, starting from the captured data and using suitable metrics. Johnson and Jakeman (1997) obtained a correlation between client satisfaction and client loyalty, while Jeanes (1996) identified a significant relationship between financial performance and clients' satisfaction. It is important to map the correlations between various dimensions of companies' performance. The advantages of this approach are explained by Panchioli et al. (2007) (identification of leading indicators, predictive performance measurement and solutions to the issue of taxation).

Slow economic growth, high competition, and restructuring of the construction industry have put strong pressure on construction companies to continually improve their productivity and performance. Several studies on performance measurement have been carried out at the project level (Stapenhurst, 2009).

Nowadays, the necessity for the evaluation of management and performance at the microeconomic level has increased. The study of Ali, Al-Sulaihi, and Al-Gahtani (2013) emphasized that the usual financial indicators are no longer enough to describe companies' success. Greater importance is attributed to planning effectiveness, safety, business efficiency, and customer satisfaction.

The high level of competition in the business environment forces companies to improve their performance. Performance is placed at the centre of continuous improvement by Lu et al. (2008). The evaluation of performance ought to help managers and members in determining the traction and direction and speed of development for their firm (Cokins, 2006). Any company should identify its weaknesses and strengths and to apply the best practices in order to obtain the best 
performance (Stapenhurst, 2009). The first step is to identify those performance indicators that are most suitable for the firm. The selection of a benchmark to ensure a comparison is the second step. There are approaches that present the key performance indicators, especially at the project level. These indicators are dependent on the countries where the companies are located.

In the UK a lot of performance measurement systems were financially biased and the systems for external reporting were not suitable for use in business enterprises. Therefore, various solutions were proposed in order to solve this issue; a balance between external and internal measures, a hierarchy of measures including the firm's performance, four perspectives of balance scorecard. These approaches are multi-dimensional insisting on non-financial indicators to redress the balance. This balance includes internal performance and external environment, indicators of past achievements and measures for future success. This approach is designed to answer the question: "what specific measures should the firm use?". However, there are serious limits: a certain recommendation is not provided for applying a performance measurement system. In the UK government declaration the relevant performance measures are recommended in order to get business success on labour market (McWilliams \& Siegel, 2000).

GRAI (Graphs with Results and Actions Inter-related) methodology was used by Britton (1990) for company modeling using the following chain: planning and control were divided into discrete decision making elements and a specific performance measure was attributed to each decision. A performance measurement questionnaire was proposed by Dixon et al. (1990) to get the strengths and weaknesses in the performance evaluation management. Then, a workshop is proposed for development and revision of the performance measures. The balance scorecard approach was used by Kaplan and Norton (1993). In this case, interviews with senior manager team are utilized in order to minimize the differences in strategic priorities. Eccles and Pyburn (1992) proposed a process in which managers have to think in detail about a performance model that links the modifications in people's knowledge and the processes of organization by assessing financial performance and market performance.

In literature more performance dimensions were proposed: financial performance (capital structure, liquidity, profitability, market ratios etc.), competitiveness (relative market position or share, growth in sales), service's quality (communication, security, reliability, appearance, comfort, cleanliness, access, availability etc.), resource utilization (efficiency, productivity), flexibility (speed and specification of delivery flexibility, volume flexibility) and innovation (performance of individual innovations and of innovative process) (Barnett \& Salomon, 2012).

The issue regarding the relationship between corporate social performance and the financial one is a topic that was deeply analyzed in the recent studies from literature. The empirical analyses checked the relationship between different types of corporate social responsibility and financial performance. The results are contradictory and a general opinion has not been formulated yet. Some studies found a negative relationship between the two elements (Vance, 1975; Wright and Ferris, 1997). A mixed relationship was identified by Cochran and Wood (1984) and by Hillman and Keim (2001). There is no significant relationship for McWilliams and Siegel (2000). A positive link was proved by Orlitzky, Schmidt and Rynes (2003) who showed that high social performance was associated with a good financial performance. 
Other opinions were formulated in recent studies. For example, Barnett and Salomon (2012) proved that the relationship between the two types of performances is $U$ shaped. The companies with low corporate social performance had higher financial performance compared to the companies with moderate social performance. On the other hand, the companies with high social performance are those with the highest corporate financial performance. These results are explained by the fact that stakeholder influence capacity had the capacity to bring profit from social responsibility. Saeidi et al. (2015) used a number of 205 production and manufacturing companies from Iran to check the relationship between corporate social responsibility (CSR) and financial performance. The author showed that the social responsibility had a positive effect on financial performance because of the positive effect of the CSR (corporate social responsibility) on competitive advantage, client satisfaction and consumer satisfaction.

Ameer and Othman (2012) checked if firms that use a set of responsibilities in the direction of ensuring sustainable practices had a better performance compared to those companies that do not agree with these practices. The author chose 100 world companies in 2008 from emerging markets and developing countries. The results of the analysis indicated that there was a reciprocal causality between practices of social responsibility and financial performance of the firms. In 2008, higher net profit, sales, return on assets and cash flows were registered in some economic activities of the firms from that sample compared to a control sample from the period 2006-2010.

Flammer (2015) used the regression discontinuity method to check if corporate social responsibility brings financial performance. The implementation of good practices regarding social responsibility in a company leads to a higher labour productivity and to increases in sales which bring corporate financial performance.

There is a consistent literature studying the relationship between company financial performance and women on boards. Post and Byron (2015) combined the results presented in a number of 140 studies and examined the variation in results due to social and cultural context and to legal/regulatory conditions. The female board representation is directly correlated with accounting returns. The evidence is stronger in those states with stronger shareholder protections. It seems that shareholder protections encourage boards to utilize the experience, varied knowledge and values of each member of the board. The relationship between market performance and female board representation is, in general, not significant. However, there is a positive correlation in those countries that have greater gender parity. A possible explanation for this result might be related to the fact that gender differences in human resources may affect investors' assessments of the future earning potential of companies with female directors.

An empirical analysis will be made in this study to assess the financial performance of London companies. Therefore, in the next section some methodological problems will be briefly discussed.

\section{METHODS, DATA AND VARIABLES}

As we stated before, the main aim of this paper is to assess the financial performance of a sample of companies from London. The analysis is based on quantitative methods: principal components analysis and cluster analysis. 
The principal components analysis (PCA) is considered as an orthogonal linear transformation. This method has the advantage of reducing the number of variables. It also avoids the problem of multicollinearity between variables.

The principal components method starts from initial variables $x^{1}, x^{2}, \ldots, x^{p}$ (a number of $\mathrm{p}$ initial variables), that are correlated and replace them with less other variables (principal components $\left.c^{1}, c^{2}, \ldots\right)$. The new variables are linear combinations of the initial variables that check the next properties:

- The principal components are of maximal dispersion and not inter-correlated;

- For information conservation, the initial variables and the principal components are correlated.

If $c^{d}$ is strongly correlated with $\nsim$, then individuals with a strong positive coordonate on first axis have a value greater than average for $\chi j$ (Hair et al., 2006).

The classification methods have to ensure the data synthesizing by grouping the individuals in classes as to have similar individuals in the same class and different ones in distinct classes. There are hierarchical and non-hierarchical methods of classification. The hierarchical methods provide rows of partitions in larger classes while the other ones provide a partition in a fixed number of classes. In the case of hierarchical methods, the Ward technique uses of grouping criterion the fusion between two classes for which there is a minimum loss of inertia between classes. In this case, the distance between 2 classes is represented by the loss of inertia between classes by their fusion. Non-hierarchical methods are used when the number of classes is known. The distance between individuals is the Euclidian distance. The main goal of each classification is to get as much as possible homogenous classes as to have a low variability inside a class. The procedure in this case starts with $\mathrm{k}$ random classes and the individuals are changed between classes as to minimize the variability inside the classes and to maximize the variability between groups (Hair Jr, Anderson \& Tatham, 1986).

The variables used in this study are: book to market- btm, cash flow, cash to asset, leverage and sales. The data refers to 293 companies from United Kingdom in 2014. The data sources are: Bloomberg, Datastream and Wharton Research Data Service. A short description of the variables in the analysis will be made. In a similar study, Chen, Cheng and Hwang (2005) made an empirical investigation of the relationship between financial performance and market valuation of the companies.

Capital expenditures are a type of expenditures that alter the business future evolution. The capital expenditure is incurred exactly when the business spends money but not with the aim to buy other fixed assets or add value to a fix asset.

Cash flow (CF) takes into account the fact that the money goes into or out of a certain business, project, business, or financial product. Cash flow is computed as a ratio:

$$
C F=\text { (income before taxes }+ \text { depreciation }) /(\text { total asset })
$$


Book to market (BTM) is employed to compute a company's value by comparing the book value with the market value. The book value is based on the company's historical cost or the accounting value. The market value is calculated in the stock market by the market capitalization:

$$
B T M=(\text { book value }) /(\text { market value })
$$

The leverage is a way to multiply the losses. Usually, it refers to buying more of an asset using the borrowed funds, under the assumption an asset income or asset price appreciation will be higher with respect to the borrowing cost. In most cases, the leverage measures the risk that borrowing costs will be higher compared to the asset income or the asset value will fall, supposing incurred losses. The financial leverage ratio is:

$$
\text { leverage }=(\text { average total assets }) /(\text { average total equity) }
$$

A sale is a commodity exchange for a service or money in return for money or it supposes the fact of selling something.

\section{A STATISTICAL ANALYSIS OF LONDON COMPANIES INDICATORS}

Principal component analysis is a very useful tool for identifying patterns in high volume data. We are interested in finding the variables that better explain the company's financial performance. Therefore, we start from an initial set of variables, all of them describing different sides of financial performance. On the other hand, the cluster analysis allows us to identify some groups of firms with similar characteristics of companies in a group (Hair et al., 2006).

In Table 1, the correlation matrix between variables is presented. Analyzing this matrix, the groups of well correlated variables can be identified.

Tab. 1 - Correlation matrix between variables

\begin{tabular}{|c|c|c|c|c|c|c|}
\cline { 3 - 7 } \multicolumn{1}{c|}{} & BTM & Cash flow & Cash to asset & leverage & sales \\
\cline { 2 - 7 } & & 1.000 & .235 & -.160 & .404 & .011 \\
\cline { 2 - 7 } Correlation flow & .235 & 1.000 & -.337 & -.017 & .048 \\
\cline { 2 - 7 } & $\begin{array}{c}\text { Cash to } \\
\text { asset }\end{array}$ & -.160 & -.337 & 1.000 & -.254 & -.061 \\
\cline { 2 - 7 } & Leverage & .404 & -.017 & -.254 & 1.000 & .046 \\
\cline { 2 - 8 } & Sales & .011 & .048 & -.061 & .046 & 1.000 \\
\hline
\end{tabular}

From the correlation table, we observed low correlations between variables. A stronger and positive relationship was observed between leverage and book to market (coefficient of correlation=0.404). The result is in accordance with the findings in literature that proved a positive correlation without any economic arguments for this relationship. A possible reason for the positive relation could be the existence of a sub-sample of firms with low book-to-market ratio. 
Tab. 2 - Communalities

\begin{tabular}{|l|c|c|}
\cline { 2 - 3 } \multicolumn{1}{c|}{} & Initial & Extraction \\
\hline BTM & 1.000 & .623 \\
\hline Cash-flow & 1.000 & .739 \\
\hline $\begin{array}{l}\text { Cash to } \\
\text { asset }\end{array}$ & 1.000 & .570 \\
\hline Leverage & 1.000 & .777 \\
\hline Sales & 1.000 & .082 \\
\hline
\end{tabular}

The communalities table (Tab. 2) indicated that book to market, cash flow, leverage and cash to asset explained the most part of the variation. These variables will form the principal components in the end.

Tab. 3 - The total variance explained (extraction Method: Principal Component Analysis)

\begin{tabular}{|c|c|c|c|c|c|c|}
\hline \multirow{2}{*}{ Component } & \multicolumn{3}{|c|}{ Initial Eigenvalues } & \multicolumn{2}{|c|}{ Extraction Sums of Squared Loadings } \\
\cline { 2 - 7 } & Total & $\begin{array}{c}\% \text { of } \\
\text { variance }\end{array}$ & $\begin{array}{c}\text { Cumulative } \\
\%\end{array}$ & Total & $\begin{array}{c}\% \text { of } \\
\text { variance }\end{array}$ & $\begin{array}{c}\text { Cumulative } \\
\%\end{array}$ \\
\hline 1 & 1.705 & 34.094 & 34.094 & 1.705 & 34.094 & 34.094 \\
\hline 2 & 1.086 & 21.723 & 55.817 & 1.086 & 21.723 & 55.817 \\
\hline 3 & 0.99 & 19.798 & 75.615 & & & \\
\hline 4 & 0.773 & 15.467 & 91.082 & & & \\
\hline 5 & 0.446 & 8.918 & 100 & & & \\
\hline
\end{tabular}

The Kaiser criterion identified two principal components for which the eigenvalues are greater than 1 . The rest of the principal components have eigenvalues less than 1 and they are not too relevant for explaining financial performance. $34.094 \%$ of the variation is explained by the first principal component, while the second principal component explains $21.723 \%$ of the variation as the results in Tab. 3 show.

Tab. 4 - The component matrix

\begin{tabular}{|l|c|c|}
\cline { 2 - 3 } \multicolumn{1}{c|}{} & \multicolumn{2}{c|}{ Component } \\
\cline { 2 - 3 } \multicolumn{1}{c|}{} & 1 & 2 \\
\hline BTM & $\mathbf{0 . 7 1 1}$ & 0.343 \\
\hline cash-flow & 0.554 & $\mathbf{- 0 . 6 5 8}$ \\
\hline cash to asset & $\mathbf{- 0 . 6 7 3}$ & 0.343 \\
\hline Leverage & 0.647 & $\mathbf{0 . 5 9 9}$ \\
\hline Sales & 0.148 & -0.245 \\
\hline
\end{tabular}

The first principal component is represented by book to market and cash to asset. The book to market has a positive correlation while cash to asset a negative one. The first principal component refers to cash reserves. The second principal component is due to cash flow (negative 
impact) and leverage (positive impact). It refers to the company capacity to attract financial resources. So, the financial performance can be synthesized for London companies by two main dimensions: book to market and cash to asset on the one hand and cash flow and leverage on the other hand.

A cluster analysis was conducted in order to identify some groups of companies according to the values of the mentioned variables. The initial and final cluster centers and distances between final cluster centers are shown in Tab. 5 .

Tab. 5 - Initial and final cluster centers and distances between final cluster centers

\begin{tabular}{|c|c|c|c|c|c|}
\hline \multicolumn{2}{|c|}{ Initial Cluster Centers } & \multicolumn{2}{c|}{ Final Cluster Centers } & \multicolumn{2}{c|}{$\begin{array}{c}\text { Distances between Final } \\
\text { Cluster Centers }\end{array}$} \\
\hline cluster 1 & cluster 2 & cluster 1 & cluster 2 & cluster 1 & cluster 2 \\
\hline 0.46 & 0 & 0.22 & 0 & 0.185 & 0.185 \\
\hline
\end{tabular}

Convergence is achieved due to no or small change in cluster centers. The maximum absolute coordinate change for any center is 0.000 , as it is shown in Tab. 6 . The current iteration is 5 . The minimum distance between initial centers is 0.461 .

Tab. 6 - Iteration history

\begin{tabular}{|c|c|c|}
\hline \multirow{2}{*}{ Iteration } & \multicolumn{2}{|c|}{$\begin{array}{c}\text { Change in cluster } \\
\text { centers }\end{array}$} \\
\cline { 2 - 3 } & 1 & 2 \\
\hline 1 & 0.125 & 0.035 \\
\hline 2 & 0.061 & 0.002 \\
\hline 3 & 0.047 & 0.002 \\
\hline 4 & 0.013 & 0.001 \\
\hline 5 & 0 & 0 \\
\hline
\end{tabular}

Two clusters were identified for which distances were calculated with respect to the average of each cluster.

The F tests should be used only for descriptive purposes because the clusters have been chosen to maximize the differences among cases in different clusters. The significance levels that were observed are not corrected for this and thus cannot be interpreted as tests of the hypothesis that the cluster means are equal. The ANOVA procedure in this form, given in Tab. 7, indicated significant differences between the two clusters.

Tab. 7 - The ANOVA procedure

\begin{tabular}{|l|l|l|l|l|l|}
\hline \multicolumn{2}{|l|}{ cluster } & \multicolumn{2}{l|}{ Error } & F & sig. \\
\hline mean square & df & mean square & df & & \\
\hline 0.456 & 1 & 0.001 & 269 & 377.191 & 0 \\
\hline
\end{tabular}


In the first cluster 14 companies were selected. Most of the firms are located in the second cluster (257 companies). 22 of the firms were not placed in the two clusters. Most of the firms, those placed in the second group, had a successful financial performance in 2014. The companies in the first cluster encountered some difficulties regarding cash flows and sales. These firms had a lower performance in 2014 and their problems might be explained by the difficulties in recovery after the economic recession in 2008.

A one-sample Kolmogorov-Smirnov test was applied to check if the data series for investment, cash-to-flow ratio, book-to-market ratio, cash-to-assets ratio, leverage, and sales follow a normal distribution (see Table 8). The normality assumption is checked to analyze whether the conclusions related to this sample can be extended to the entire population of UK companies.

Tab. 8 - Kolmogorov- Smirnov test

\begin{tabular}{|c|l|c|l|}
\hline $\begin{array}{c}\text { Current } \\
\text { number }\end{array}$ & Null hypothesis & Sig. & Decision \\
\hline 1 & $\begin{array}{l}\text { The distribution of investment is normal, with a mean } \\
\text { of } 0.04 \text { and a standard deviation of 0.05. }\end{array}$ & 0.000 & $\begin{array}{l}\text { Reject the null } \\
\text { hypothesis. }\end{array}$ \\
\hline 2 & $\begin{array}{l}\text { The distribution of cash flow is normal, with a mean of } \\
0.96 \text { and a standard deviation of } 1 .\end{array}$ & 0.000 & $\begin{array}{l}\text { Reject the null } \\
\text { hypothesis. }\end{array}$ \\
\hline 3 & $\begin{array}{l}\text { The distribution of the book-to-market ratio is normal, } \\
\text { with a mean of 0.01 and a standard deviation of } 0.25 .\end{array}$ & 0.000 & $\begin{array}{l}\text { Reject the null } \\
\text { hypothesis. }\end{array}$ \\
\hline 4 & $\begin{array}{l}\text { The distribution of the cash-to-assets ratio is normal, } \\
\text { with a mean of 0.16 and a standard deviation of } 0.19 .\end{array}$ & 0.000 & $\begin{array}{l}\text { Reject the null } \\
\text { hypothesis. }\end{array}$ \\
\hline 5 & $\begin{array}{l}\text { The distribution of leverage is normal, with a mean of } \\
0.46 \text { and a standard deviation of } 0.32 .\end{array}$ & 0.064 & $\begin{array}{l}\text { Retain the null } \\
\text { hypothesis. }\end{array}$ \\
\hline 6 & $\begin{array}{l}\text { The distribution of sales is normal, with a mean of } 4 \\
641.12 \text { and a standard deviation of } 32700.34 .\end{array}$ & 0.000 & $\begin{array}{l}\text { Reject the null } \\
\text { hypothesis. }\end{array}$ \\
\hline
\end{tabular}

According to the Kolmogorov-Smirnov test, only the data set for leverage followed a normal distribution, with an average of 0.46 , and the standard deviation equalled 0.32 .

For the other data series, the null hypothesis of normal repartition is rejected with a significance level of 0.05 . In the case of normal distribution, the inferences can easily be made for the entire population of companies from United Kingdom.

All in all, in order to improve their financial performance the companies from the United Kingdom should pay attention to the improvement of their book-to-market ratio and cash-to-assets ratio. After these indicators are improved, it is recommended to take into account whether there are problems regarding cash flow and leverage.

\section{CONCLUSION}

In the context of a high level of competition between firms, financial performance is an important objective that is followed by managers in a company. There are various ways to evaluate 
the financial performance of a company, but the researchers agree that an aggregate measure is necessary. In order to respond to this issue, a principal components analysis was conducted using more initial variables related to financial performance. Another important advantage of the application of this method is the fact that it identifies the most relevant variables that should be considered in the assessment of financial performance. In the future, managers will only concentrate on the values of those important variables when assessing the financial performance. On the other hand, managers will focus in the initial phase on the improvement of these indicators to the detriment of other financial variables.

In this study, 293 London companies with various profiles were analyzed, using the assessment of their financial performance for 2014. A cluster analysis was conducted and two groups were identified. Most of the firms, those placed in the second cluster, had a successful financial performance in 2014. The companies in the first cluster encountered some difficulties regarding cash flow and sales. These firms had a lower performance in 2014. These results might be explained by the difficulty of recovering after the economic crisis.

The financial performance can be synthesized for London companies by two main dimensions: their book-to-market ratio and cash-to-assets ratio on the one hand, and cash flow and leverage on the other hand. However, this research is limited by the consideration of only some variables, those that are included in the database. Indicators related to social issues might also be relevant in ensuring a certain financial performance. Managerial factors should adjust the financial problems in time in order to avoid low performance.

In future research, this empirical research could be extended by including other types of indicators to measure another dimension of performance, such as corporate social performance, that could explain the financial results. In this case, the relationship between social responsibility and financial performance might be studied if the database is extended with other variables.

\section{References}

1. Ali, H. A. E. M., Al-Sulaihi, I. A., \& Al-Gahtani, K. S. (2013). Indicators for measuring performance of building construction companies in Kingdom of Saudi Arabia. Journal of King Saud University-Engineering Sciences, 25(2), 125-134. doi:10.1016/j.jksues.2012.03.002

2. Ameer, R., \& Othman, R. (2011). Sustainability practices and corporate financial performance: A study based on the top global corporations. Journal of Business Ethics, 108(1), 61-79. doi:10.1007/s10551-011-1063-y

3. Barnett, M. L., \& Salomon, R. M. (2012). Does it pay to be really good? Addressing the shape of the relationship between social and financial performance. Strategic Management Journal, 33(11), 1304-1320. doi: 10.1002/smj.1980

4. Britton, M. (1990). Methods of design and establishment systems of measure performance for organizations industrializes. Bordeaux: University of Bordeaux I.

5. Chen, M. C., Cheng, S. J., \& Hwang, Y. (2005). An empirical investigation of the relationship between intellectual capital and firms' market value and financial performance. Journal of intellectual capital, 6(2), 159-176. http://dx.doi.org/10.1108/14691930510592771 
6. Cochran, P., \& Wood, R. (1984). Corporate social responsibility and financial performance. Academy of Management Journal, 27, 42-56.

7. Cokins, G. (2006). Performance management. Case studies in Performance Management: A Guide from the Experts. New Jersey: John Wiley \& Sons.

8. Dixon, R., Nanni,A., \& Vollmann, T. (1990). The new performance change: measuring operations for world-class competition. Business One Irwin, Irwin: Homewood.

9. Eccles, R., \& Pyburn, P. (1992). Creating a comprehensive system to measure performance. Management Accounting 74(4), 41-44.

10. Flammer, C. (2015). Does corporate social responsibility lead to superior financial performance? A regression discontinuity approach. Management Science, 61(11), 2549-2568. http://dx.doi.org/10.1287/mnsc.2014.2038

11. Hair Jr, J. F., Anderson, R. E., \& Tatham, R. L. (1986). Multivariate data analysis with readings. Macmillan Publishing Co., Inc.

12. Hair, J. F., Black, W. C., Babin, B. J., Anderson, R. E., \& Tatham, R. L. (2006). Multivariate data analysis (Vol. 6). Upper Saddle River, NJ: Pearson Prentice Hall.

13. Hillman, A., \& Keim, G. (2001). Shareholder value, stakeholder management, and social issues: What's the bottom line? Strategic Management Journal, 22(2), 125-139. DOI: 10.1002/1097-0266(200101)22:2<125::AID-SMJ150>3.0.CO;2-H

14. Jeans, C. (1996). Customer satisfaction and business results: is there a link?. Customer service management 1 , 46- 48 .

15. Johnson, T., \& Jakeman, M. (1997). The customer challenge- the inside story of a remarkable transformation in customer service. London: Pitman.

16. Kaplan, R., \& Norton, D. (1993). Putting the balanced scorecard- measures that drive performance. Hardvard Business Review, September/October 1993, 134-147.

17. Kaplan, R., \& Norton, D. (1996). The balanced scorecard +/- translating strategy into action. Boston: Harvard Business School Press.

18. Luu, V.-T., Soo-Young K., \& Huynh, T.A. (2008). Improving project management performance of large contractors using benchmarking approach. International Journal of Project Management 26(7), 758-769. doi:10.1016/j.ijproman.2007.10.002

19. McWilliams, A., \& Siegel, D. (2000). Corporate social responsibility and financial performance: Correlation or misspecification? Strategic Management Journal, 21 (5), 603-609. DOI: 10.1002/(SICI)1097-0266(200005)21:5<603::AID-SMJ101>3.0.CO;2-3

20. Orlitzky, M., Schmidt, F. \& Rynes, S. (2003). Corporate social and financial performance: A meta-analysis. Organization Studies, 24, 403-441. doi: 10.1177/0170840603024003910

21. Pancholi, J., Ghaffari, F., \& Ahmed, Z. (2007). Business Performance Measurement Indicators of Selected Uk Companies. In European Association for Comparative Economics Studies (EACES) 9th Bi-Annual Conference: Development Strategies-A Comparative View.

22. Post, C., \& Byron, K. (2015). Women on boards and firm financial performance: A metaanalysis. Academy of Management Journal, 58(5), 1546-1571. doi: 10.5465/amj.2013.0319 
23. Saeidi, S. P., Sofian, S., Saeidi, P., Saeidi, S. P., \& Saaeidi, S. A. (2015). How does corporate social responsibility contribute to firm financial performance? The mediating role of competitive advantage, reputation, and customer satisfaction. Journal of Business Research, 68(2), 341-350. doi:10.1016/j.jbusres.2014.06.024

24. Stapenhurst, T. (2009). The benchmarking book. London: Routledge.

25. Vance, S. (1975). Are socially responsible corporations good investment risks? Management Review, 64, 18-24.

26. Wright, P., Ferris, S. (1997). Agency conflict and corporate strategy: The effect of divestment on corporate value. Strategic Management Journal, 18, 77-83.

\section{Contact information}

Habilitated Dr. Mihaela Simionescu

Romanian Academy

Institute for Economic Forecasting

Calea 13 Septembrie 13

76001 Bucharest, Romania

E-mail:mibaela_mb1@yahoo.com 